\title{
First China-France International Symposium of Biorheology
}

\section{FIRST ANNOUNCEMENT}

The first China-France International Symposium of Biorheology will be beld in Beijing, China, Aug. 31-Sept.2, 1994. It is sponsored by French Society of Biorheology (Chairman J.F STOLTZ), Chinese Society of Biorhology (Chairman WU YUN-PENG) and chinese society of Biomechanics, CSTAM (Chairman YANG GUi-TONG).

The Organizing Committee would like to extend our cordial invitation to all peoples to attend, the first China-France International Symposium. The main themes of the symposium are theoretical and experimental biorheology, hemorheology and clinical hemorheology, molecular biorheology, hemorheology and hemodynamics, hemorheology and microcirculation, tissue engineering and rheology, and for promoting the exchanges of scholar achievements and cooperation on biorheology. September is the best season for you to enjoy and visit a great number of historical places and scenic spots and the traditional east atmosphere.

Dates : Aug.31-Sept.2, 1994 and a one-day tour including the Great Wall and one of the Ming Tombs. Place : Beijing Hotel, Beijing, China

Call for Papers : deadline of receiving papers : May 1, 1994. All submitted papers should be made camera-ready in English with a typing area of $145 \times 210 \mathrm{~mm}$ and must not be longer than 4 pages.

Accomodations : The Symposium will be held at Beijing Hotel, the rate will be as follow :

Single Room : about US\$100 per night

Double Room : about US\$ 55 per person-night

Registration Fee : FF. 2000 (for delegates) (about 340 US\$). including proceedings, welcoming party, banquet, break tea and a one day tour.

If you wish to be included on the circulation list, and for further informations concerning this Symposium, please contact Professor J.F. STOLTZ or Doctor HE Lin at the following addresses :

Prof. J.F. STOLTZ

Centre Régional de Transfusion et d'Hématologie

Brabois - Avenue de Bourgogne

54500 VANDOEUVRE-Lès-NANCY - FRANCE

Fax : (33) 83.44.60.46 Tel. : (33) 83.44.62.62

Dr. HE Lin

The Chinese Society of Theoretical and Applied Mechanies

No. 15 Zhong Guancun Road

BEIJING 100080, CHINA

Fax : (86-1) $2561284 \quad$ Tel. : (86-1) 2559588

Telex 222554 MEHAS CN 